\title{
Physical-chemical Evaluation and Texture Profile of Yoghurts Supplemented with Achachairu Pulp
}

\section{(Garcinia humilis)}

Sâmela Leal Barros(Coresponding Author), Newton Carlos Santos, Renata Duarte Almeida, Victor Herbert de Alcântara Ribeiro, Israel Luna Alves, Josivanda Palmeira Gomes, Raphael Lucas Jacinto Almeida, Márcia Ramos Luiz, Amanda Priscila Silva Nascimento, Mylena Olga Pessoa Melo, Danise Medeiros de Vieira, Vírginia Mirtes de Alcântara Silva, Tamires dos Santos Pereira

Federal University of Campina Grande, Campina Grande, Paraíba, Brazil E-mail: samelaleal7@gmail.com

Received: Sep. 11, 2019

doi:10.5296/jas.v8i1.15422
Accepted: Oct. 9, 2019

Published: Oct. 20, 2019

URL: https://doi.org/10.5296/jas.v8i1.15422

\begin{abstract}
Yogurt is defined as being the product obtained through the fermentation of milk, its pleasant taste and high nutritional value are the main factors responsible for the acceptance of the product in the market. The present study aims to evaluate the physicochemical and textural properties of a yoghurt supplemented with 0, 5, 10, 15 and 20\% Acacchairu pulp. Fresh pulp and yoghurt were submitted to the following physicochemical analyzes: moisture content and total solids, $\mathrm{pH}$, total titratable acidity, total soluble solids, ratio, water activity, vitamin $\mathrm{C}$ and lipids. Regarding the texture profile, only yogurts were evaluated the following parameters: firmness, consistency, cohesiveness and viscosity index. Achachairu pulp presented high moisture content and water activity, as well as low percentage of lipids. Higher values were obtained regarding moisture content, water activity, acidity, lipids and vitamin $\mathrm{C}$ in the formulations with higher pulp percentage and for all texture attributes the formulation with $0 \%$ pulp obtained the highest values. The formulations proposed with the addition of different pulp concentrations improved the physicochemical and texture attributes of yogurt.
\end{abstract}

Keywords: Achachairu pulp, yoghurt, firmness, sensory attributes

\section{Introduction}

The pursuit of healthier diets has grown exponentially among consumers, and the increased demand for nutritious foods has made the development of healthier products one of the priorities of the food industry. In this context, fermented milks stand out for having high 
potential for the development of new products, mainly because they are considered beneficial to health (Bessa et al., 2018).

Yogurt is the product obtained by the fermentation of milk, which occurs through microorganisms (Streptococcus thermophilus and Lactobacillus delbrueckii subsp.bulgaricus), the milk base must be above $70 \%$ and the addition of vegetable fat is not allowed. They are considered as foods of high nutritional value and high added commercial value. Among existing dairy products, yogurts and dairy drinks stand out for their numerous nutritional and therapeutic properties and are essential for achieving a balanced diet and are therefore highly popular (Souza et al., 2018).

Representing a trend in the consumption of healthier products, the addition of fruits in dairy products improves the nutritional and sensory value of foods. For fruits and vegetables are rich in bioactive compounds such as vitamins, antioxidant compounds and fiber. Just as the importance of developing new products is considered, there must be a constant search for solutions to probiotic stability, quality and viability problems in new food matrices such as fruits, cereals and other vegetables (Barbosa et al., 2017).

Achachairu (Garcinia humilis) originated in Bolivia, but is currently grown in different regions such as Brazil, since the soil and weather conditions are suitable for its growth and fruiting. This species produces fruits with a large seed inside and white pulp, characterized by its juiciness and pleasant sweet taste. The fruit also stands out for presenting high nutritional value, presenting in its composition antioxidant compounds as total phenolic compounds, vitamins and essential minerals. Therefore, it has high technological potential and can be used as raw material in various production processes (Silva et al., 2018; Tome et al., 2019).

One of the parameters that most influence the sensory acceptance of yogurt is the texture and desorption of yogurt, knowledge of these parameters is essential for the development of food products and for establishing a correlation between physical and sensory parameters. Consumers usually prefer smooth texture, viscous body without syneresis and consistency so that they can be eaten with the spoon (Gurjão et al., 2015; Egea et al., 2019).

In this context, the present study aims to evaluate the physicochemical and textural properties of a yoghurt supplemented with Acacchairu pulp in different concentrations while considering its viability as a new tradable food product.

\section{Material and Methods}

The present work was developed at the Milk Derivatives Laboratory of the Academic Unit of Food Engineering, Federal University of Campina Grande (UFCG), Brazil.

Achachairus (Garcinia humilis) were purchased at CEASA Recife Central Supply Center, Pernambuco, transported in thermal boxes to the laboratory, where they were washed in sodium hypochlorite solution at $200 \mathrm{ppm}$ for $15 \mathrm{~min}$ and then rinsed in running water. Then, with the help of a domestic knife, the fractions: peel, pulp and seed of the fruits were separated. 


\subsection{Yoghurt Processing}

For the preparation of the inoculum, commercial whole milk powder was used and reconstituted as described on its packaging It was heated at $80{ }^{\circ} \mathrm{C}$ for 15 minutes, cooled to $45 \pm 1{ }^{\circ} \mathrm{C}$. After inoculum preparation, commercial culture of Streptococcus salivarius subsp was inoculated. thermophilus, incubating at $45 \pm 1{ }^{\circ} \mathrm{C}$ for 4 hours (until desired acidity is reached). After this fermentative period the inoculum was kept refrigerated for later use. Four different concentrations of achachairu pulp $(5,10,15,20 \%)$ were added to the whole yogurt. For each formulation the incubation procedure described above was performed. Each elaborated formulation was packed in plastic containers previously sterilized in boiling water.

\subsection{Physicochemical Characterization of Achachairu Pulp and Yogurts}

Fresh pulp and yoghurt were characterized in triplicate for the following physicochemical coatings: moisture content and total solids, $\mathrm{pH}$, total titratable acidity, total soluble solids ( ${ }^{\circ}$ Brix) and acid ratio (SST/ATT) according to the methodology of the Adolfo Lutz Institute (Brazil, 2008). The water activity of the samples was determined in Aqualab 3TE (Decagon, Devices USA) at room temperature $\left(25^{\circ} \mathrm{C}\right)$. Lipid content by the modified Blig and Dyer method (1959); Vitamin C content was determined by the reaction of ascorbic acid with 2,6-dichlorophenol indophenol (DCFI), according to the procedure described by Brasil (2008), and the results were expressed in $\mathrm{mg}$ of ascorbic acid/100g sample.

\subsection{Texture Profile Determination}

Texture profile analysis (TPA) was performed on a universal texturometer TA-XT plus -Texture Analyzer by Stable Micro Systems equipped with the software. Exponent Stable Micro Systems, using the P-36R probe, to obtain firmness, consistency, cohesiveness and viscosity index attributes.

\subsection{Statistical Analysis}

Experimental data were analyzed in triplicate and the results were subjected to 5\% probability one-way analysis of variance (ANOVA) and significant qualitative responses were submitted to Tukey test adopting the same 5\% significance level. For the development of statistical analysis, the Assistat 7.7 software (Silva \& Azevedo, 2016) was used.

\section{Results and Discussion}

Table 1 shows the results obtained for the physical and chemical characterization of achachairu pulp. 
Table 1. Physicochemical characterization of achachairu pulp in natura

\begin{tabular}{ll}
\hline Parameters & Pulp in natura \\
\hline Moisture (\%) & $89.61 \pm 0.33$ \\
Water activity $\left(\mathrm{A}_{\mathrm{w}}\right)$ & $0.991 \pm 0.001$ \\
$\mathrm{pH}$ & $3.35 \pm 0.14$ \\
ATT $(\%$ citric acid) & $8.03 \pm 0.012$ \\
SST $\left({ }^{0}\right.$ Brix $)$ & $15.0 \pm 0,001$ \\
Total solids $(\%)$ & $10.39 \pm 0.33$ \\
Ratio (SST/AT) & $18.67 \pm 0.28$ \\
Vitamin C (mg of ascorbic acid/100g sample) & $9.61 \pm 0.18$ \\
Lipids $(\%)$ & $0.48 \pm 0.009$ \\
\hline
\end{tabular}

Table 1 shows that the sample has high moisture content (89.61\%) and water activity (0.99). Tome et al. (2019) obtained similar value in achachairu pulp (80.68\%). Lemos et al. (2019) found a moisture content of 90.29 and water activity of 0.991 in Jabuticaba pulp.

An acidic $\mathrm{pH}$ (3.35) and high acidity (0.80\%) were observed in Acacchairu pulp in natura, similar to that observed by Barros et al. (2019) in pineapple pulp, which presented $\mathrm{pH}$ of 3.79 and acidity of $0.51 \%$ citric acid.

The soluble solids content obtained in the present work $\left(15^{\circ}\right.$ Brix $)$ was similar to that observed by Melo et al. (2017) in their studies with fruits of Achachairu collected in different parts of the plant, presenting a variation from 14.08 to $16.36{ }^{\circ}$ Brix. According to Pimentel Junior et al. (2019), this parameter indicates the degree of fruit ripeness, higher values of this parameter indicate a high degree of ripeness.

The ratio parameter was calculated through the relationship between soluble solids content and $\mathrm{pH}$, giving a value of 18.67. Morgado et al. (2019) obtained values similar to those observed in the present study regarding this parameter when analyzing the storage of jabuticaba, which presented a $\mathrm{pH}$ of 18.1 to 25.2 .

Were quantified $9.61 \mathrm{mg}$ of ascorbic acid/100g sample, higher than determined by Virgolin et al. (2017) in fresh pulp of achachairu (5.60 mg/100g), abiu (3.06 mg/100g) and azara (5.60 $\mathrm{mg} / 100 \mathrm{~g})$. The lipid content obtained in the present study $(0.48 \%)$ was higher than that reported by Santos et al. (2019) in pineapple pulp (0.11\%), plum (0.06\%), persimmon $(0.04 \%)$, orange $(0.13 \%)$, apple $(0.05 \%)$, papaya $(0.12 \%)$, passion fruit $(0.37 \%)$, melon $(0.02 \%)$, strawberry $(0.27 \%)$ and grape $(0.08 \%)$. 
Table 2 shows that the results obtained from the physicochemical characterization of yoghurt elaborated in the different concentrations of Acacchairu pulp, being 0, 5, 10, 15 and $20 \%$.

Table 2. Physicochemical characterization of yogurt with acchairuu pulp

\begin{tabular}{|c|c|c|c|c|c|}
\hline \multirow{2}{*}{ Parameters } & \multicolumn{5}{|c|}{ Formulations } \\
\hline & $\mathrm{F} 1(0 \%)$ & $\mathrm{F} 2(5 \%)$ & F3 $(10 \%)$ & F4 (15\%) & F5 (20\%) \\
\hline Moisture (\%) & $83.57 \pm 0.07^{\mathrm{d}}$ & $84.24 \pm 0.01^{\mathrm{c}}$ & $85.46 \pm 0.03^{\mathrm{b}}$ & $85.67 \pm 0.02^{\mathrm{a}}$ & $85.76 \pm 0.03^{\mathrm{a}}$ \\
\hline Water activity $\left(\mathrm{A}_{\mathrm{w}}\right)$ & $0.969^{\mathrm{a}}$ & $0.971^{\mathrm{a}}$ & $0.978^{\mathrm{a}}$ & $0.983^{\mathrm{a}}$ & $0.985^{\mathrm{a}}$ \\
\hline $\mathrm{pH}$ & $4.28 \pm 0.02^{\mathrm{a}}$ & $4.27 \pm 0.08^{\mathrm{a}}$ & $4.26 \pm 0.01^{\mathrm{a}}$ & $4.21 \pm 0.01^{\mathrm{a}}$ & $4.22 \pm 0.17^{\mathrm{a}}$ \\
\hline $\begin{array}{l}\text { Total titratable acidity } \\
\text { (\%lactic acid) }\end{array}$ & $0.47 \pm 0.01^{\mathrm{e}}$ & $0.51 \pm 0.01^{\mathrm{d}}$ & $0.58 \pm 0.01^{\mathrm{c}}$ & $0.65 \pm 0.01^{\mathrm{b}}$ & $0.68 \pm 0.01^{\mathrm{a}}$ \\
\hline Total soluble solids ( ${ }^{\circ}$ Brix) & $10.0 \pm 0.01^{\mathrm{d}}$ & $10.1 \pm 0.01^{\mathrm{cd}}$ & $14.54 \pm 0.01^{\mathrm{c}}$ & $14.33 \pm 0.23^{\mathrm{d}}$ & $14.23 \pm 0.16^{\mathrm{d}}$ \\
\hline Total solids (\%) & $16.43 \pm 0.07^{\mathrm{a}}$ & $10.1 \pm 0.01^{\mathrm{cd}}$ & $10.50 \pm 0.03^{\mathrm{c}}$ & $11.66 \pm 0.02^{\mathrm{b}}$ & $11.70 \pm 0.02^{\mathrm{b}}$ \\
\hline Ratio (SST/ATT) & $21.28 \pm 0.36^{\mathrm{a}}$ & $19.80 \pm 0.31^{\mathrm{b}}$ & $18.10 \pm 0.25^{\mathrm{c}}$ & $17.17 \pm 0.20^{\mathrm{c}}$ & $17.20 \pm 0.39^{\mathrm{c}}$ \\
\hline $\begin{array}{l}\text { Vitamin C (mg of ascorbic } \\
\text { acid/100g sample) }\end{array}$ & $0.79 \pm 0.04^{\mathrm{d}}$ & $2.99 \pm 0.46^{c}$ & $3.42 \pm 0.01^{\mathrm{c}}$ & $5.25 \pm 0.05^{\mathrm{b}}$ & $6.53 \pm 0.41^{\mathrm{a}}$ \\
\hline Lipids $(\%)$ & $1.00 \pm 0.04^{\mathrm{c}}$ & $1.11 \pm 0.06^{\mathrm{c}}$ & $1.26 \pm 0.03^{\mathrm{b}}$ & $1.31 \pm 0.01^{\mathrm{ab}}$ & $1.39 \pm 0.03^{\mathrm{a}}$ \\
\hline
\end{tabular}

Through Table 2, it can be observed that the moisture content between the samples ranged from 83.57 to $85.76 \%$, lower values regarding this parameter were observed in formulations containing lower pulp percentage. No statistical difference was observed between the samples regarding water activity, which varied from 0.969 to 0.985 . According to Meneses et al. (2018), these parameters cause a reduction in the quality and microbiological stability of food, influencing its degradation. Bessa and Silva (2018) reported a similar result when determining the moisture content of tamarind prebiotic yogurt (82.26 to $83.72 \%)$.

No statistical difference was observed between the samples regarding $\mathrm{pH}$, which ranged from 4.21 to 4.28 . However, the samples differed statistically with respect to total titratable acidity. It can be observed that the increase in the percentage of pulp used in the formulations caused the acidity increase of the product, which ranged from 0.47 to $0.68 \%$ of lactic acid. This fact is justified based on the physicochemical characterization of Acacchairu pulp in natura, described in Table 1, which found that the sample has high acidity. Magalhães and Torre (2018) obtained similar values when evaluating the $\mathrm{pH}$ and acidity of Greek-type yogurt, 
where the $\mathrm{pH}$ ranged from 4.26 to 4.40 and the acidity ranged from 1.07 to 1.37 .

The total solids content ranged from 10.1 to $16.66 \%$. Regarding the soluble solids content, sample F1 had a lower value (10 ${ }^{\circ}$ Brix) and sample F3 had a higher value (14.54) when compared to the other samples. Oriente et al. (2019) obtained values higher than the present study regarding this parameter, when evaluating yoghurt with plum pulp and whole chia flour, which presented a variation of 26.67 to $30.23^{\circ}$ Brix.

With respect to ratiofa observed a variation from 17.20 (F5) to 21.28 (F1), according to Morgado et al. (2019), this parameter is capable of indicating the sweetness of the product. Therefore, it was observed that the samples containing the lowest percentage of Achachairu pulp presented higher sweetness.

The yoghurt with acchairuu pulp was high in vitamin $\mathrm{C}$ and a statistically significant difference was found between all samples, ranging from 0.79 to $6.53 \mathrm{mg}$ of ascorbic acid/100g sample. The vitamin $\mathrm{C}$ content was directly proportional to the pulp content used in the formulations. Marinho et al. (2012) obtained lower values regarding the concentration of this vitamin in yogurt with the addition of umbu pulp (0.49 to $0.78 \mathrm{mg} / 100 \mathrm{~g})$.

The lipid content of the samples ranged from 1.00 (F1) to $1.39 \%$ (F5), similar to that observed by Silveira et al. (2017) in yoghurt with added green banana biomass (2.50 to 2.57\%). Bezerra et al. (2019), when evaluating Greek-type yogurt, found a high lipid content (5.75 to $7.45 \%$ ), this high fat concentration is caused due to the technological drainage process.

The instrumental texture parameters of the yoghurt added from achachairu pulp are presented in Table 3. Through the analysis of variance, it was observed that the addition of achachairu pulp caused a significant difference $(\mathrm{p}<0.05)$ for the firmness, cosistence parameters. cohesiveness and viscosity index evaluated by the instrumental method.

Table 3. Instrumental firmness, consistency, cohesiveness and viscosity index of yoghurts added from achachairu pulp $(0,5,10,15$ and $20 \%)$

\begin{tabular}{ccccc}
\hline \multirow{2}{*}{$\begin{array}{c}\text { Formulation } \\
(\%)\end{array}$} & Firmness (N) & Consistency (N.s) & $\begin{array}{c}\text { Cohesiveness } \\
(\mathrm{N})\end{array}$ & $\begin{array}{c}\text { Viscosity index } \\
(\text { N.s })\end{array}$ \\
\cline { 2 - 5 } & $0.804 \pm 0.012^{\mathrm{a}}$ & $19.313 \pm 0.04^{\mathrm{a}}$ & $0.780 \pm 0.023^{\mathrm{a}}$ & $2.322 \pm 0.121^{\mathrm{z}}$ \\
\hline 0 & $0.520 \pm 0.02^{\mathrm{bc}}$ & $12.257 \pm 0.01^{\mathrm{bc}}$ & $0.403 \pm 0.011^{\mathrm{b}}$ & $1.322 \pm 0.041^{\mathrm{b}}$ \\
5 & $0.603 \pm 0.011^{\mathrm{b}}$ & $13.600 \pm 0.02^{\mathrm{b}}$ & $0.381 \pm 0.010^{\mathrm{b}}$ & $1.199 \pm 0.012^{\mathrm{b}}$ \\
10 & $0.577 \pm 0.001^{\mathrm{bc}}$ & $13.086 \pm 0.011^{\mathrm{bc}}$ & $0.434 \pm 0.012^{\mathrm{b}}$ & $1.341 \pm 0.041^{\mathrm{b}}$ \\
15 & $0.462 \pm 0.021^{\mathrm{c}}$ & $10.385 \pm 0.02^{\mathrm{c}}$ & $0.330 \pm 0.008^{\mathrm{b}}$ & $0.960 \pm 0.011^{\mathrm{b}}$ \\
\hline
\end{tabular}


It can be observed that the firmness of yogurts decreases with increasing pulp concentration. It is also observed that only the $0 \%$ formulation presents statistical difference from the other significant ones ( $p>0.05)$. Almeida et al. (2019) when analyzing the texture of Greek-type yoghurt obtained values ranging from 0.703 to 1.121 N. According to Vianna et al. (2019), firmness is considered one of the main textural parameters for yogurt acceptability.

As for consistency there was a variation 10.385 to 19.313 N.s., the yogurt without added pulp presented the highest value $(19.313 \mathrm{~N})$ differing from the other formulations $(\mathrm{p}>0.05)$. Almeida Neta et al. (2018) when evaluating the texture profile during 21 days of storage of milk whey desserts and jabuticaba peel ingredients obtained values ranging from 8.35 to 13.46 N.s, which are close to those reported in the present study. According to Mousavi et al. (2018) Consistency is defined as the internal bond strengths, which keep the product as perfect, and is expressed as the content strength that can cause a material to deform before it is broken, this parameter has a strong influence on the acetability of the product.

Regarding the cohesiveness values, it can be seen in table 3 that the formulations with 5, 10, 15 and $20 \%$ of pulp do not present significant differences ( $>$ > 0.05). The attributes for this parameter were reduced with increase in pulp percentage and temperature increase. According to Mantovani et al. (2012) the cohesiveness allows to evaluate the resistance of the product to dissolve during the taster tasting and to evaluate this attribute in yoghurts made with different concentrations of total solids obtained values ranging from 0.600 to $0.830 \mathrm{~N}$.

As with the other texture parameters evaluated, the viscosity index also presented similar behavior, whereas formulations with 5, 10, 15 and 20\% pulp did not present significant differences $(\mathrm{p}>0.05)$. Higher values for this parameter were observed by Vieira et al. (2017) for yogurts made in different concentrations of lemon juice $(2,4,6$, and $8 \%$ ) in which they obtained viscosity indexes ranging from 5,928 to 8,641 N.s.

\section{Conclusion}

Achachairu pulp presented high moisture content and water activity, besides low percentage of lipids. The proposed yoghurt formulations with the addition of different pulp concentrations increase the physicochemical attributes among them, moisture content, water activity, acidity, lipids and vitamin $\mathrm{C}$. No correlation was observed between the percentage of pulp used and the parameters: $\mathrm{pH}$ and total soluble solids content. Addition of yogurt pulps also promoted reduction in all attributes evaluated in the texture profile.

\section{References}

Almeida Neta, M. C., Queiroga, A. P. R., Almeida, R. L. J., Soares, A. C., Gonçalves, J. M., Fernandes, S. S., ... Florentino, E. R. (2018). Fermented Dessert with Whey, Ingredients from the Peel of Jabuticaba (Myrciaria cauliflora) and an Indigenous Culture of Lactobacillus. Nutrients, 10(9), 1-19. https://doi.org/10.3390/nu10091214

Almeida, R. L. J., Santos, N. C., Barros, S. L., Nascimento, A. P. S., \& Silva, V. M. A. (2019). Characterization physical-chemical and textural of yogurts type greek commercialized in the city of Campina Grande-PB. Revista Higiene Alimentar, 33(288/289), 983-987. 
Barbosa, P. M., \& Gallina, D. A. (2017). Viability of bacteria (starter and probiotics) in beverages made with yogurt and mango pulp. Revista do Instituto de Laticínios Cândido Tostes, 72(2), 85-95. https://doi.org/10.14295/2238-6416.v72i2.580

Barros, S. L., da Silva, W. P., de Figueirêdo, R. M. F., de Araújo, T. J., Santos, N. C., \& Gomes, J. P. (2019). Effect of adding different types of sugar on the physicochemical quality of pineapple and cinnamon jams. Principia Journal, 45(1), 150-157. https://doi.org/10.18265/1517-03062015v1n45p150-157

Bessa, M. M., \& Silva, A. G. F. (2018). Elaboration and physical-chemical and sensory characterization of tamarind prebiotic yogurt. Revista do Instituto de Laticínios Cândido Tostes, 7 (4), 185-195. https://doi.org/10.14295/2238-6416.v73i4.581

Bezerra, K. C. A., Oliveira, E. N. A., Feitosa, B. F., Feitosa, R. M., \& Matias, J. K. S. (2019). Physicochemical and sensory profile of natural Greek yogurts made with different sucrose concentrations. Agricultural Engineering, 27(2), 89-97.

https://doi.org/10.13083/reveng.v27i2.832

Bligh, E. G., \& Dyer, W. J. (1959). A rapid method of total lipid extraction and purification. Canadian Journal Biochemistry Physiology, 37, 911-917. https://doi.org/10.1139/y59-099

Brasil, Adolfo Lutz Institute. (2008). Physicochemical methods for food analysis (4th ed., Volume 1, p.1020). São Paulo: Adolfo Lutz Institute.

Egea, M. B., Gomes, A. C. G., Lima, M. S., \& Takeuchi, K. P. (2019). Relationship between physicochemical and rheological characteristics and commercial value of strawberry-flavored whole yogurt. Food and nutrition security, 26(1), 1-11. https://doi.org/10.20396/san.v26i0.8652948

Gurjão, F. F., Carneiro, G. G., Pessoa, T., Silva, D. R. S., \& Pê, P. R. (2015). Rheological behavior of cashew yoghurt commercialized in Campina Grande, Paraíba. Verde Journal, 10(2), 257-260. https://doi.org/10.18378/rvads.v10i2.2939

Lemos, D. M., Rocha, A. P. T., Gouveia, J. P. G., Oliveira, E. N. A., Sousa, E. P., \& Silva, S. F. (2019). Elaboration and characterization of jabuticaba and acerola prebiotic jelly. Brazilian Journal of Food Technology, 22, 1-13. https://doi.org/10.1590/1981-6723.09818

Magalhães, A. U., \& Torre, A. C. G. D. (2018). Chemical composition and sensory analysis of Greek yogurt traded in the South of the state of Minas Gerais. Revistado Instituto de Laticínios Cândido Tostes, 73(1), 10-18. https://doi.org/10.14295/2238-6416.v73i1.607

Mantovani, D., Corazza, M. L., Cardozo Filho, L., \& Costa, S. C. (2012). Elaboration of yoghurt with different concentrations of solids total, analysis, chemical-physical and texture of profile. Revista Brasileira de Tecnologia Agroindustrial, 6(1), 680-687. https://doi.org/10.3895/S1981-36862012000100007

Marinho, M. V. M., Figueirêdo, R. M. F., Queiroz, A. J. M., Santiago, V. M. S., \& Gomes, J. P. (2012). Physicochemical and sensory analysis of goat's milk yogurt with umbu pulp. Brazilian Journal of Agroindustrial Products, 14, 497-510. 
https://doi.org/10.15871/1517-8595/rbpa.v14nEspecialp497-510

Melo, M. S., Benett, C. G. S., Melo, B. S., Lourenço, S. L. O., \& Barboza, F. S. (2017). Physical-chemical analysis of achachairu fruits collected in different plant parts. Revista de Agricultura Neotropical, 4(1), 17-21. https://doi.org/10.32404/rean.v4i5.2189

Meneses, V. P., Silva, J. R. A., Neto, J. F., Rolim, H. O., Araújo, A. L. M., \& Lima, P. S. E. (2018). Subprodutos de frutas tropicais desidratados por secagem convectiva. Revista Verde de Agroecologia e Desenvolvimento Sustentável, 13(4), 472-482. https://doi.org/10.18378/rvads.v13i4.5810

Morgado, C. M., Guariglia, B. A., Trevisan, M. J., Façanha, R., Jacomino, A. P., Corrêa, G., \& Cunha Junior, L. C. (2019). Quality assessment of jabuticabas (cv. sabará), submitted to refrigerated storage and conditioned in different packaging.Revista Interdisciplinar Da Universidade Federal Do Tocantins, 6(2), 18-25.

https://doi.org/10.20873/uft.23593652201962p18

Mousavi, M., Heshmati, A., Garmakhany, A. D., Vahidinia, A., \& Taheri, M. (2018). Texture and sensory characterization of functional yogurt supplemented with flaxseed during cold storage. Food Science \& Nutrition, 7, 907-917. https://doi.org/10.1002/fsn3.805

Oriente, S. F., Silva, P. I. S., Gouveia, D. S., Mota, M. M. A., Dantas, R. L., \& Santiago, A. M. (2019). Elaboração e caracterização físico-química de iogurtes de ameixa adicionados da farinha de chia. Magistra, 30, 78-85. https://doi.org/10.17648/enag-2018-91833

Pimentel Junior, L. A., Domingues Neto, F. J., Silva, M. J. R., \& Tecchio, M. A. (2019). Production, quality and maturity grape 'syrah' in condition subtropical of Brasil. Brazilian Journal of Biosystems Engineering. 13(1), 72-79.

https://doi.org/10.18011/bioeng2019v13n1p72-79

Santos, B. A., Teixeira, F., Amaral, L. A., Randolpho, G. A., Kélin, S. K., Santos, E. F., ... Novello, D. (2019). Chemical and nutritional characterization of fruit pulp stored under freezing. Revista da Universidade Vale do Rio Verde, 17(1), 1-13. https://doi.org/10.5892/ruvrd.v17i1.5049

Silva, B. L. B., Costa, E., Binotti, F. F. S., Benett, C. G. S., \& Silva, A. G. (2018). Growth and quality of Garcinia humilisseedlings as a function of substrate and shading level. Revista Pesquisa Agropecuária Tropical, 48(4), 407-413.

https://doi.org/10.1590/1983-40632018v4853500

Silva, F. A. S., \& Azevedo, C. A. V. (2016). The Assistat Software Version 7.7 and its use in the analysis of experimental data. African Journal Agricultural Research, 11, 3733-3740. https://doi.org/10.5897/AJAR

Silveira, A. C. R., Silva, M. A. P., Moura, L. C., Souza, D. G., Plácido, G. R., \& Caliari, M. (2017). Parâmetros físico-químicos e sensoriais de iogurtes com biomassa da banana verde. Global Science and Technology, 10(1), 29-42.

Souza, T. S. P., Luna, A. S., Barros, D. B., Pimentel, T. C., Pereira, E. P. R., Guimarães, J. T., 
\& Cruz, A. G. (2018). Yogurt and whey beverages available in Brazilian market: Mineral and trace contents, daily intake and statistical differentiation. Food Research International, 18(1), 1-27. https://doi.org/10.1016/j.foodres.2018.10.050

Tome, A. C., Mársico, E. T., Silva, F. A., Kato, L., Nascimento, T. P., \& Monteiro, M. L. G. (2019). Achachairú (Garcinia humilis): chemical characterization, antioxidant activity and mineral profile. Journal of Food Measurement and Characterization, 13, 213-221. https://doi.org/10.1007/s11694-018-9934-x

Vianna, F. S., Canto, A. C. V. C., Lima, B. C., Salim, S. P., Balthazar, C. F., Costa, M. P., ... Silva, A. C. O. (2019). Milk from different species on physicochemical and microstructural yoghurt properties. Ciência Rural, 49(6), e20180522.

https://doi.org/10.1590/0103-8478cr20180522

Vieira, A. F., Silva, R. R. L., Alves, D. E. G., Morais, H. M. B. R., \& Santos, D. C. (2017). Processamento e caracterização de iogurte de limão. Revista Brasileira de Tecnologia Agroindustrial, 11(2), 2420-2436. https://doi.org/10.3895/rbta.v11n2.3180

Virgolin, L. B., Seixas, F. R. F., \& Janzantti, N. S. (2017). Composition, content of bioactive compounds, and antioxidant activity of fruit pulps from the Brazilian Amazon biome. Pesquisa Agropecuária Brasileira, 52(10),

933-941. https://doi.org/10.1590/s0100-204x2017001000013

\section{Copyright Disclaimer}

Copyright for this article is retained by the author(s), with first publication rights granted to the journal.

This is an open-access article distributed under the terms and conditions of the Creative Commons Attribution license (http://creativecommons.org/licenses/by/4.0/). 